\title{
How Satisfied are Greek EFL Teachers with their Work? Investigating the Motivation and Job Satisfaction Levels of Greek EFL Teachers
}

\author{
EVDOKIA KARAVAS \\ National and Kapodistrian University of Athens
}

Received: 26 February 2009 / Accepted: 8 December 2009

ISSN: 1697-7467

\begin{abstract}
The unstable and adverse working conditions Greek EFL (English as a Foreign Language) teachers are called to operate within as well as the scarcity of research on EFL teachers' job satisfaction more generally, prompted this study which aimed at identifying the job satisfaction levels and sources of motivation of Greek EFL teachers. The findings of this survey shed light on the factors/issues that affect EFL teachers' motivation and that need to be taken into account by educational policy makers and school advisors, if high quality public school foreign language education is to be achieved.
\end{abstract}

Keywords: EFL teachers, job satisfaction, teacher motivation

¿Cómo están de satisfechos los profesores griegos de inglés como lengua extranjera con su trabajo? Investigación de la motivación y de los niveles de satisfacción de trabajo del profesorado de inglés en Grecia.

RESUMEN: Las difíciles condiciones de trabajo de los profesores de inglés como lengua extranjera ('EFL') y la escasez de encuestas sobre la satisfacción del trabajo del profesorado de inglés da lugar a esta investigación, la cual espera identificar los niveles de satisfacción de trabajo y las fuentes de motivación de los docentes griegos de inglés. Los resultados de esta investigación muestran los factores que afectan a la motivación del profesorado de inglés como lengua extranjera. Estos factores han de tener en cuenta los responsables de las políticas educativas y a la Inspección educativa si se desea conseguir un alto nivel de la enseñanza de la lengua extranjera en la escuela pública. Palabras clave: profesorado de inglés como lengua extranjera, satisfacción laboral, motivación docente

\section{INTRODUCTION}

Greek EFL teachers' career development has traditionally been unpredictable and unstable as they are expected from the onset of their career to work (many times simultaneously) in a variety of teaching contexts (primary, secondary, tertiary level, private or public education) under different kinds of constraints and within different organizational cultures. As a result they have to quickly learn to cope with and adjust to different groups of students of varying 
ages, language levels, varying levels of motivation, varying interests and concerns. In addition, in recent years, massive educational reforms involving changes in foreign language teaching policies, language assessment systems and externally imposed innovative curricula, have challenged Greek teachers' existing practices and their traditionally constructed identities, have increased the complexity of teacher roles and responsibilities inevitably resulting in periods of destabilization and increased workload. Within this state of instability, Greek EFL teachers and especially the Greek public school EFL teachers also have to cope with and overcome public criticisms and the ensuing loss of public confidence in their ability to provide quality language teaching to students. Given these adverse working conditions Greek EFL teachers are called to operate within and the dearth of research on EFL teacher job satisfaction and Greek teachers' job satisfaction more generally, this study set out to investigate how satisfied Greek EFL teachers feel with their job, what motivates them, how they manage to sustain their motivation and remain in the teaching profession.

\section{Teacher JOB SATISFACTION}

Teacher motivation and job satisfaction have become a central area of concern for many educational contexts which are experiencing high teacher attrition rates, i.e. teachers increasingly leaving the profession after a few years in service (see for instance, Shann, 1998 for attrition rates of beginning teachers in the US and Huberman, 1993, Woods et al., 1997 for teachers in the UK and Australia). Moreover, studies worldwide have found that teachers report the highest level of occupational stress (Kyriakou and Sutcliffe, 1979), and that they are less satisfied with their jobs than any other professional group (Neves De Jesus and Lens, 2005). As Zembylas and Papanastasiou (2004) argue, research into and concern with teacher satisfaction is becoming more and more important not only because teachers are leaving the profession but also because job dissatisfaction is associated with decreased commitment and productivity, reduced ability to meet student needs, significant incidences of psychological disorders leading to absenteeism and high levels of stress related disability (see also on Farber 1982, Day, 2002, Hargreaves, 1994,1998, Houtte, 2006). On the other hand, high levels of job satisfaction have been found to positively influence the quality of teaching, student self esteem and commitment, and ultimately student performance and student achievement. Satisfied teachers are also more likely to work for educational reforms and progressive legislation (see Bishay, 1996, Day, 2002, Neves De Jesus and Lens, 2005, Morgan and O'Leary, 2004, Papanastasiou and Zembylas, 2005, Shann, 1998, Woods and Weasmer, 2004).

Job satisfaction is a multidimensional and dynamic construct affected by many factors relating to individual characteristics, to features of the working context and to specific aspects of the job (Koustelios, 2005). Various definitions of job satisfaction have been proposed (see for instance Evans, 1997, 2001, Koustelios, 2005, Papanastasiou and Zembylas, 2005, Zembylas and Papanastasiou, 2004) but in general job satisfaction equates with how an individual feels about his job (Dinham and Scott, 1998). According to Evans (2001, p. 294), job satisfaction refers to "a state of mind encompassing all those feelings determined by the extent to which the individual perceives her/his job related needs to be being met" Similarly, teacher satisfaction "refers to a teacher's affective relation to his her teaching role and is a function of the perceived relationship between what one wants from teaching and what one perceives it is 
offering to a teacher". (Zembylas and Papanastasiou 2004, p.359). Teacher motivation and job satisfaction are different constructs but inextricably linked as one influences the other. Generally speaking, motivation refers to an innate stimulus for behaviour and action, an inner drive which inspires us to act in the light of a particular context, whereas job satisfaction refers to a product of a behaviour or action in the light of a particular context (Dinham and Scott, 1998).

Research on teacher job satisfaction has identified a variety of factors that affect job satisfaction and teacher motivation. These factors fall into (see Dinham and Scott, 1998) three main categories/domains:

1) Factors intrinsic to teaching (factors relating to the core business of teaching)

2) Factors operating at the school level (relating to the conditions under which work must be performed)

3) Factors operating at the system level (factors relating to the wider domain of society, the state government and the system)

\subsection{Factors intrinsic to teaching}

The vast majority of studies (e.g. Day et al 2006, Dinham and Scott, 1998, Evans, 2001, Farber, 1982, Papanastasiou and Zembylas, 2006, Scott and Dinham, 2003, Shann, 1998, Zembylas and Papanastasiou, 2004), conclude that the main factors found to contribute to teacher job satisfaction relate to the actual work of teaching, that is, working with children, developing warm personal relationships with children, the intellectual challenge of teaching, autonomy and independence and having opportunities to try out new ideas. Teachers, regardless of sex, teaching experience, position held and location and type of school, have been found to derive their greatest satisfaction and experience a great sense of achievement through working with and for young people and by assisting young people to realize their potential, experience success and grow into responsible adults. Teachers universally have been found to treasure student enthusiasm and responsiveness as a vital factor of their own enthusiasm while listing students' low motivation as a discourager. In other words, just as working with students and affecting their lives is the most central and potent source of satisfaction for teachers, working with difficult and demotivated students may have negative repercussions for teacher satisfaction and can be the source of emotionally draining and discouraging experiences (Houtte, 2006).

\subsection{Factors operating at the school level}

The second source of factors affecting job satisfaction comprise largely school based factors such as school leadership, school climate and participation in decision making, support from leadership and peers, school infrastructure, the school's relation with its local community, workload, staff supervision, class size, school communication networks (Dinham and Scott, 1998). These are factors extrinsic to the task of teaching but can become powerful dissatisfiers when absent or problematic. The importance of a school culture with strong support networks that promotes collaboration, communication, collegiality has been identified by many studies (Dinham and Scott, 1998, Farber, 1982, Morgan and O'Leary, 2004, Papanastasiou and Zembylas, 2005, Woods and Weasmer, 2004) as a central determinant of teacher job satisfaction. 


\subsection{Factors operating at the system level}

The third source of factors includes those emanating from the wider social context, the state government and the system. These are factors are extrinsic to the job itself and include imposed educational change, increased expectations on schools to deal with and solve social problems, community's opinion of teachers, the image of teachers portrayed in the media, level of support by the system to implement curricular changes, support services to teachers, promotion prospects, status of teachers, conditions of service, salary (Farber, 1982, Hargreaves, 1994, Kelly, 1997, Shann, 1998). Teachers generally view job dissatisfaction as principally emanating from work overload, poor pay and perceptions of how teachers are viewed by society (Zembylas and Papanastasiou, 2004). These extrinsic, systemically based factors have been identified as powerful dissatisfiers which detract from or militate from the core business of teaching and which can significantly affect teachers' motivation and their desire to remain in teaching.

\subsection{Teacher job satisfaction and teacher efficacy}

Another important construct in the study of teacher job satisfaction which affects how teachers deal with and manage sources of job dissatisfaction is the concept of teacher efficacy (Day et al, 2006). Teacher efficacy refers to the self perception of teaching competence; it is the self belief of teachers that they can exert a positive effect on their students' progress and success (Tschannen-Morran and Woolfolk-Hoy, 1998). Teachers with a high sense of efficacy have been found to exhibit greater enthusiasm for and commitment to teaching, display greater willingness to cope with students' emotional and behavioural difficulties, exhibit greater desire and readiness to experiment and find better ways of teaching and generally exhibit higher levels of job satisfaction (Bandura, 1997, Morgan and O' Leary, 2004, Pajares, 1997). Justification of the importance of teacher efficacy and its relation to job satisfaction is provided by Morgan et al. (2007:.3) who state

"teacher efficacy has at least two important motivational outcomes...Firstly it influences the kind of challenges and environments teachers are prepared to face in their work. If teachers believe that teaching difficult subject matter or working with colleagues will overwhelm them (low self efficacy) they will avoid these situations in favour of less challenging and ultimately less beneficial learning contexts. Secondly, strong self efficacy beliefs influence effort and persistence. Teachers with high self efficacy quickly recover following set backs in their teaching efforts and this resilience is crucial in helping students to maintain their persistence and self belief".

\section{Aims AND CONTEXT OF THE STUDY}

Given the conceptual framework discussed above and taking into account the lack of research on Greek teachers' job satisfaction and the adverse working conditions Greek EFL teachers are called to operate within, this study aimed at identifying the job satisfaction levels and sources of motivation of Greek EFL teachers. More specifically, the study set out to investigate 
a) how satisfied Greek EFL teachers felt in relation to i) factors operating at the school based level and ii) factors relating to wider domain of society,

b) how various factors relating to school culture, student attitudes and behaviour and the task of teaching (intrinsic factors) affected teachers' motivation, commitment to teaching and their concepts of self efficacy,

c) the reasons that motivated teachers to enter the EFL profession.

A questionnaire (see Appendix 1) consisting of closed questions was developed and after being pilot tested with a small sample of EFL teachers was sent electronically to $400 \mathrm{EFL}$ teachers throughout Greece. The number of completed questionnaires received was 224 giving a response rate of $56 \%$. The questionnaire consisted of four main parts: Part 1 elicited biographical information from teachers (age, sex, years of teaching experience, types of schools/institutions in which they have taught, geographical region of schools/institutions in which they have taught). Part 2 consisted of a series of 15 Likert type statements focusing on the first research question of the study. This part of the questionnaire asked respondents questions related to their level of satisfaction with various aspects extrinsic to the task of teaching such as their recognition by students, peers, parents and the wider community, the image of teachers, their statues in society, their salary, working hours, benefits etc. The questions in this part were measured on a 5 point scale ranging from $1=$ highly satisfying to $5=$ highly dissatisfying. Part 3 , consisted of a series of 20 Likert type statements focusing on the second research question of the study. More specifically, this part of the questionnaire elicited respondents' attitudes towards various school based factors, towards their work and their relationship with students. The questions in this part were measured on a 5 point scale ranging from $1=$ strongly agree to $5=$ strongly disagree. Finally, Part 4 investigated teachers' reasons for entering teaching/ choosing teaching as a career.

\section{Findings OF THE STUDY}

\subsection{Respondents' biodata}

The vast majority of respondents were predictably women (almost 90\%), with the majority $(42,2 \%)$ being in their thirties while a fair number of respondents were at the beginnings of their teaching career $(29,6 \%)$.

More than $1 / 3$ of the respondents had 10 to 20 years of teaching experience (the average number of years of teaching experience was 13), indicating that a fair number of the teachers who had participated in the study are in their mid career stage being well socialized into the profession and having put down firm roots into the profession. It should be noted at this point that teachers belonging to this career stage often become disenchanted and marginalize themselves from learning (Day et al 2006); they are most vulnerable to self doubts regarding the wisdom of their career choice. According to Farber (1982:14) "this group too is most "locked into" teaching - feeling too old and unprepared to change careers yet too young to think about retirement."

The findings regarding types of schools/institutions in which respondents have taught in the past, clearly reveal the unpredictability and instability of the of the Greek EFL teachers' 
career path. Almost all respondents have taught in a wide range of institutions and organizational cultures while the vast majority $(81,7 \%)$ have taught in private language schools. What is also clear from the results is that the majority of Greek EFL teachers have not taught in one type of school full time from the start of their career but have taught in a range of schools especially in the public sector at the same time on a part time basis.

As far as their current place of employment is concerned, the findings reveal a more stable and clearer picture. More than half $(50,4 \%)$ of the respondents now teach in the public educational sector on a full time basis while an extremely small percentage $(1,3 \%)$ still teach in private language schools.

Finally, regarding the geographical location of the schools in which teachers are currently teaching, most of the respondents teach in large cities throughout Greece $(56,7 \%)$ while over $1 / 3$ of the respondents $(33 \%)$ teach in schools located in rural areas.

\subsection{Reasons for choosing teaching as a profession}

Similar to other international studies regarding the reasons individuals choose teaching as a career (Barmby, 2006, Day et al. 2006, Moran et al. 2001), the majority of respondents chose to enter the EFL profession mainly on the basis of altruistic and intrinsic factors (see Table 1). Most respondents entered the teaching profession driven by altruistic motives such as their desire to work with young people and to help students to succeed (82\%) and the potential of teaching in changing students' lives. Respondents were equally motivated by intrinsic reasons such as their interest in and love for their subject (statements 6 and 7). More than half of the respondents also valued the security teaching offered (statement 3). Extrinsic reasons such as salary and benefits, promotion prospects and status of the profession were the least powerful motivators for entering the teaching profession.

Table 1: Reasons for entering teaching.

\begin{tabular}{|c|c|}
\hline \multicolumn{2}{|c|}{$\begin{array}{l}\text { I. What were your main reasons for entering the teaching profession (tick more than } \\
\text { one if necessary) }\end{array}$} \\
\hline 1. Working with young people & $82 \%$ \\
\hline 2. Salary and benefits & $27,2 \%$ \\
\hline 3. Job security & $55,4 \%$ \\
\hline Teaching fitted in with my lifestyle/family situation & $46 \%$ \\
\hline Variety in teaching & $31,3 \%$ \\
\hline Mentally stimulating work & $61,6 \%$ \\
\hline 7. Love of the subject & $78,1 \%$ \\
\hline 8. $\quad$ Promotion prospects & $0,9 \%$ \\
\hline 9. Contributing to society & $35,3 \%$ \\
\hline 10. Status of the profession & $13,8 \%$ \\
\hline 11. Potential of changing students' lives/attitudes & $46,9 \%$ \\
\hline 12. $\quad$ Family approval & $17,9 \%$ \\
\hline 13. Other (please state) & $3,1 \%$ \\
\hline
\end{tabular}




\subsection{Teachers' attitudes towards system based factors}

The first part of the questionnaire investigated teachers' degree of satisfaction with various factors extrinsic to the task of teaching - namely school based factors and especially system based factors (i.e. factors of the wider social domain).

Results will be presented in descending order, starting from those factors the respondents seemed to be most satisfied with and proceeding to factors they seemed less satisfied or dissatisfied with.

Table 2: Extrinsic factors respondents seemed most satisfied with.

\begin{tabular}{|c|c|c|c|}
\hline How satisfying do you find: & Satisfying & $\begin{array}{l}\text { Neither satisfying } \\
\text { nor dissatisfying }\end{array}$ & Dissatisfying \\
\hline $\begin{array}{l}\text { 1. the amount of recognition you receive for } \\
\text { your efforts from your students. }\end{array}$ & 83,1 & 12,1 & 4,0 \\
\hline $\begin{array}{l}\text { 2. your benefits (holidays, educational leaves } \\
\text { etc.). }\end{array}$ & 72.3 & 17,4 & 8,4 \\
\hline $\begin{array}{l}\text { 3. your "official" working hours (in terms of } \\
\text { quantity). }\end{array}$ & 62,9 & 22,3 & 13,4 \\
\hline $\begin{array}{l}\text { 4. the amount of recognition you receive for } \\
\text { your efforts from people in your school. }\end{array}$ & 60,3 & 34,4 & 3,1 \\
\hline $\begin{array}{l}\text { 5. the amount of recognition you receive for } \\
\text { your efforts from parents and your } \\
\text { community. }\end{array}$ & 59,9 & 28,6 & 10,2 \\
\hline 6. your status as an EFL teacher in society. & 55,4 & 30,8 & 13,0 \\
\hline $\begin{array}{l}\text { 7. your status as an EFL teacher in your } \\
\text { school. }\end{array}$ & 48,2 & 37,5 & 11,2 \\
\hline $\begin{array}{l}\text { 8. the amount of recognition you receive for } \\
\text { your efforts from your employer/school } \\
\text { governing body. }\end{array}$ & 45,1 & 37,1 & 14,7 \\
\hline
\end{tabular}

The majority of Greek EFL teachers (see Table 2) seem to be most satisfied with the recognition they receive for their efforts from their students $(83,1 \%)$, with the benefits of their job $(72 \%)$, their official working hours $(62.9 \%)$ and the recognition they receive for their efforts from people in their school $(60,3 \%)$ and from parents $(59,9 \%)$. A significant number of teachers also felt satisfied with their status as an EFL teacher in society $(55,4 \%)$ and in their school $(48,2 \%)$ and the recognition they receive for their efforts from their employers or school governing bodies $(45,1 \%)$. Interestingly, in relation to these last three factors, over $1 /$ 3 of the respondents felt neither satisfied nor dissatisfied signifying that a fair number of teachers felt that there was room for improvement as far as their status in society and in school and the recognition they receive from their employers is concerned. 
Table 3: Extrinsic factors respondents seemed dissatisfied with

\begin{tabular}{|l|c|c|c|}
\hline How satisfying do you find: & Satisfying & $\begin{array}{l}\text { Neither } \\
\text { satisfying nor } \\
\text { dissatisfying }\end{array}$ & Dissatisfying \\
\hline $\begin{array}{l}\text { 9. the way that governments work for the } \\
\text { betterment of your status. }\end{array}$ & 5,8 & 17 & 76,8 \\
\hline 10. your salary. & 10,3 & 30,4 & 58,9 \\
\hline $\begin{array}{l}\text { 11. your opportunities for promotion or } \\
\text { advancement }\end{array}$ & 10,2 & 29,9 & 57,2 \\
\hline $\begin{array}{l}\text { 12. the physical working environment of your } \\
\text { school (infrastructure, resources etc.). }\end{array}$ & 26,8 & 21,4 & 48,2 \\
\hline $\begin{array}{l}\text { 13. the range of professional in-services } \\
\text { courses/programmes/support offered to EFL } \\
\text { teachers }\end{array}$ & 24,1 & 29,9 & 44,2 \\
\hline
\end{tabular}

As far as sources of dissatisfaction are concerned (see Table 3), the majority of respondents seemed dissatisfied with system based factors such as the state's initiatives for improving the status of EFL teachers $(76,8 \%)$, their salary $(58,9 \%)$, opportunities for promotion $(57,2 \%)$. Almost half of the respondents also felt dissatisfied with the infrastructure and resources of their working environment and opportunities for their professional development offered by the state.

These results are in accord with results from international research on teachers' job satisfaction (Cross and Harris, 2006, Dinham and Scott, 1998, Scott and Dinham, 2003, Shann, 1998) where the most strongly felt dissatisfiers were phenomena extrinsic to the task of teaching, and largely out of the control of teachers and schools found within the domain of the state government and the system (see Dinham and Scott, 1998, for the Results of the Teacher 2000 Project which investigated the job satisfaction levels of a large number of teachers and school executives in the UK, US and Australia). It is also interesting to note that these results coincide with the results of a study on the job satisfaction levels of physical education teachers in Greece carried out by Koustelios in 2005. Physical education teachers in Greece were also found to be strongly dissatisfied with their promotional opportunities, their salaries and their working conditions.

Another two factors extrinsic to teaching, received quite interesting results. Public perception of EFL teachers and how they are portrayed in the media (see Table 4) was a source of dissatisfaction for $1 / 3$ of the respondents $(32.6 \%)$ while almost half of the respondents $(48,2 \%)$ felt that there was room for improvement. A final factor that elicited interesting results regarded the way that professional associations work (such as PEKADE, TESOL etc) work for the improvement of the ELT profession. Respondents were divided on this issue: slightly over 1/ 3 of the teachers felt satisfied with the services of professional associations, slightly over $1 / 3$ felt dissatisfied and nearly one third expressed a neutral attitude feeling neither satisfied nor dissatisfied. 
Table 4: System based factors respondents were ambivalent about

\begin{tabular}{|l|c|c|c|}
\hline How satisfying do you find: & Satisfying & $\begin{array}{l}\text { Neither } \\
\text { satisfying nor } \\
\text { dissatisfying }\end{array}$ & Dissatisfying \\
\hline $\begin{array}{l}\text { 14. the image of EFL teachers as portrayed in } \\
\text { the media. }\end{array}$ & 17,4 & 48,2 & 32,6 \\
\hline $\begin{array}{l}\text { 15. the way that educational professional } \\
\text { associations work for the betterment of your } \\
\text { profession. }\end{array}$ & 35,7 & 29 & 34,3 \\
\hline
\end{tabular}

\subsection{Teachers' attitudes towards school based factors}

The second part of the questionnaire investigated teachers' attitudes towards various school based factors such as such as school leadership, school climate, support from leadership and peers, school communication networks. As was mentioned before, these are factors extrinsic to the task of teaching but can become powerful dissatisfiers when absent or problematic. Moreover this part of the questionnaire also included statements relating to factors intrinsic to the task of teaching such as the quality of teacher student relationship, teachers' sense of efficacy and teachers' feelings regarding their work (challenge of teaching, commitment to teaching etc.) which act as powerful sources of motivation for teachers as mentioned above.

As far as teachers' attitudes towards various school based factors are concerned (see Table 5), teachers generally felt satisfied with the opportunities and support from school administration for trying out new ideas and practices (almost $60 \%$ of respondents), they highly valued cooperation with colleagues in school (almost 70\%), and found extra curricular activities highly stimulating (73,6\%). A large number of teachers (almost $60 \%$ ) did not feel burdened by their workload. As far as the usefulness of administrative meetings for solving their problems is concerned, teachers seemed divided on this issue: nearly half of the respondents believed that administrative meetings were not conducive to solving their problems associated with their teaching tasks while over $1 / 3$ felt that they were. Finally a school culture with strong support networks that promotes collaboration, communication, collegiality is not a characteristic of all schools respondents work in, since almost half of the respondents felt satisfied with the support and communication networks present in their schools while almost the other half felt dissatisfied. 
Table 5: Teachers' attitudes towards school based factors

\begin{tabular}{|l|c|c|c|}
\hline & Agree & Don't know & Disagree \\
\hline $\begin{array}{l}\text { 16. School administration does not support my } \\
\text { efforts to try out new ideas/practices with } \\
\text { my students. }\end{array}$ & 27,7 & 12,9 & 57,2 \\
\hline $\begin{array}{l}\text { 17. Cooperation with colleagues in my school } \\
\text { is rewarding and beneficial. }\end{array}$ & 68,8 & 14,7 & 14,2 \\
\hline $\begin{array}{l}\text { 18. Extra curricular activities (school projects, } \\
\text { organizing school events etc.) are as } \\
\text { stimulating to me as teaching is. }\end{array}$ & 73,6 & 12,5 & 13 \\
\hline $\begin{array}{l}\text { 19. Administrative meetings at school are not } \\
\text { helpful in solving teachers' problems. }\end{array}$ & 45,1 & 14,3 & 37,5 \\
\hline $\begin{array}{l}\text { 20. I feel my workload (teaching and } \\
\text { administrative work) is too heavy. }\end{array}$ & 30 & 9,4 & 58,5 \\
\hline $\begin{array}{l}\text { 21. My school provides a collegial supportive } \\
\text { environment for me to work in. }\end{array}$ & 41,1 & 12,9 & 42,4 \\
\hline
\end{tabular}

Two statements in this part of the questionnaire also dealt with teachers' confidence in their ability to exert a positive effect on their students' progress and success. Teachers' sense of efficacy, as mentioned above, is a powerful motivational factor since facilitates teachers' effort and persistence despite drawbacks and difficulties to experiment and improve the quality of their teaching. As can be seen from Table 6, the majority of teachers feel confident in their ability to deal with students' problems and positively affect students' progress and achievements.

Table 6: Teachers' perceptions of their teaching efficacy

\begin{tabular}{|l|c|c|c|}
\hline & Agree & Don't know & Disagree \\
\hline $\begin{array}{l}\text { 22. I have dealt effectively with the problems } \\
\text { of my students. }\end{array}$ & 62,9 & 25,4 & 9,4 \\
\hline $\begin{array}{l}\text { 23. I have positively influenced students' lives } \\
\text { through my teaching. }\end{array}$ & 56,7 & 41,1 & 1,3 \\
\hline
\end{tabular}

\subsection{Teachers' attitudes towards factors intrinsic to teaching}

As regards teachers' attitudes towards their work, the core task of teaching, the results of the present survey are in accord with results of international surveys on teacher motivation and job satisfaction (see Table 7). More specifically a look at the highlighted statements (in italics) reveals that the majority of Greek EFL teachers find their work mentally stimulating (nearly 90\%), and view the relationship with their students as the most rewarding aspect of their work (over 90\%). The majority also (almost 70\%) find that teaching increases their self esteem $(68,8 \%)$ and do not show any intention of leaving the teaching profession since they express total commitment to teaching $(72,1 \%)$, and do not regret their career choice $(75,2 \%)$. 
Despite their positive attitudes towards the intrinsic aspects of their work, teachers do feel stressed and at times emotionally drained by their work. As can be seen from the results of statements 26, 30 and 31 more than half of the teachers in the sample find teaching stressful and more than $1 / 3$ have felt burnt out and emotionally drained from their work. These percentages are alarming since unmediated stress and burnout have negative repercussions for teachers' well being and physical health and significantly impair teaching quality and student motivation and achievement (Day, 2002, Farber, 1982, Morgan and O'Leary, 2004). This finding confirms results from international research where teachers report the highest levels of stress and burnout than any other professional group.

Table 7: Teachers' attitudes towards their work

\begin{tabular}{|l|c|c|c|}
\hline & Agree & Don't know & Disagree \\
\hline $\begin{array}{l}\text { 24. If I had to do it again, I would still choose } \\
\text { to become a teacher. }\end{array}$ & 75,2 & 20,5 & 4 \\
\hline $\begin{array}{l}\text { 25. I feel that working closely with young } \\
\text { people is the most fascinating aspect of my } \\
\text { work. }\end{array}$ & 93,7 & 3,1 & 1,3 \\
\hline 26. I feel emotionally drained from my work. & 29 & 9,8 & 58,9 \\
\hline $\begin{array}{l}\text { 27. I cannot see myself continuing to teach for } \\
\text { the rest of my career. }\end{array}$ & 9,8 & 27,7 & 62 \\
\hline 28. I feel total commitment to teaching. & 72,3 & 21 & 5,8 \\
\hline 29. Teaching increases my self esteem. & 68,8 & 16,1 & 13 \\
\hline 30. Teaching often stresses me. & 52,3 & 5,4 & 39,8 \\
\hline 31. I have felt burned out from my work. & 30,4 & 9,8 & 58 \\
\hline 32. I find my work mentally stimulating. & 86,6 & 7,6 & 4,4 \\
\hline
\end{tabular}

A possible explanation for the rather high levels of stress and burnout expressed by the Greek EFL teachers in the sample may be found in the problems teachers face in motivating students and dealing with their negative attitudes towards the lesson. As can be seen from Table 8, for the majority of teachers, their learners' lack of motivation for learning English , their lack of interest in their subject, and ensuing discipline problems significantly impair their own motivation and enthusiasm for teaching and have an impact on the quality of their teaching. Students' lack of motivation in the subject has been a perennial problem especially for the Greek public school EFL teacher and as evidenced by the results of this study, continues to be a source of great stress and a powerful demotivating factor for teachers themselves. 
Table 8: Teachers' attitudes towards students

\begin{tabular}{|l|c|c|c|}
\hline & Agree & Don't know & Disagree \\
\hline $\begin{array}{l}\text { 33. Students' discipline problems affect my } \\
\text { motivation and enthusiasm for teaching }\end{array}$ & 69,6 & 4 & 25 \\
\hline $\begin{array}{l}\text { 34. My students' low motivation levels for } \\
\text { learning English create great stress to me. }\end{array}$ & 54,9 & 8,5 & 35,3 \\
\hline $\begin{array}{l}\text { 35. Students' attitude problems (misbehaviour } \\
\text { in class, lack of interest in the subject etc.) } \\
\text { have an effect on the quality of my } \\
\text { teaching. }\end{array}$ & 73,2 & 4,5 & 21 \\
\hline
\end{tabular}

\subsection{The effect of age, gender and teaching experience on Greek EFL teachers' job satisfaction}

Regression analysis was performed on the results in order to see whether sex and years of experience may have an effect on respondent' levels of job satisfaction and sources of motivation. At the 5\% significance level, it was found that women are less likely than men to be highly satisfied or satisfied with the recognition they receive for their efforts from people in their school, from parents and the community and from their students. Women were also more likely to be affected by students' discipline problems in class and to experience stress and burnout in their job; women also tend to report lower self efficacy levels than men (see also Crossman and Harris, 2006 for similar results). No statistically significant differences were found as regards their satisfaction levels towards other factors or the reasons for entering teaching.

As far as years of teaching experience are concerned, teaching experience seems to affect teacher satisfaction as regards certain factors and teachers' attitudes towards work. More specifically, beginning teachers (those with 1-5 years of experience) are less likely to be satisfied with the recognition they receive for their efforts from people in their school, from parents and the community from their students, and with the way that professional organizations work for the improvement of the profession, with the physical working environment of their schools, and with their salaries.

Moreover, beginning teachers did not feel that working with young people is the most fascinating aspect of their work, and found extracurricular activities more challenging than more experienced teachers. They were more likely to state that students' discipline problems affect their motivation and enthusiasm, they tended to exhibit lower levels of self efficacy, did not find their work mentally stimulating, and did not believe that their school provided a collegial supportive environment for them. In sum, younger teachers and especially women at the very first stage of their teaching career seem to be less satisfied with their work than their older, more experienced counterparts. A similar finding is reported in the research of Kyriakou and Sutcliffe (1979). 


\section{Summary of Results and discussion}

The results of this study confirm findings from studies of teacher job satisfaction worldwide where teachers find greatest satisfaction with the intrinsic elements of their work such as interaction with students and professional autonomy and self growth and express dissatisfaction with issues related to school structures and policy making (Day, 2002, Day et al., 2006, Shann, 1998).

The results provide a fairly consistent profile of the Greek EFL teacher. Despite the fact the Greek EFL teachers are aware of instability and unpredictability that characterises their profession, they choose to enter teaching on the basis of altruistic and intrinsic reasons, motivated by their love of the subject, their desire to help children realise their potential and driven by their firm belief that they can make a difference in students' lives. They generally seem satisfied with various aspects of their work such as the recognition they receive for their efforts from students primarily and from parents, their benefits and working hours and their status as EFL teachers in school and in society. They are rather ambivalent as regards the portrayal of their profession in the media and the way professional associations work for the improvement of their profession. They express dissatisfaction with various factors operating at the government/policy making level such as the way governments work for the improvement of their status, their salaries and promotional opportunities, the quality and quantity of profession development opportunities offered to them and the physical working environment of their schools.

The majority of teachers also valued various factors associated with the school context such as their autonomy in trying out new ideas and practices, their cooperation with colleagues in school, and the challenge that extracurricular activities provide. They were ambivalent regarding the value of administrative meetings in dealing with and solving their problems, and the effectiveness of support and communication networks in their schools.

On the whole, Greek EFL teachers find their relationship and interaction with students the most rewarding aspect of their job and express total commitment to their profession having no regrets over their career choice. They exhibit rather high levels of teaching efficacy and find teaching a mentally challenging, stimulating activity which increases their confidence and self esteem.

Despite their professed commitment to their work, an alarming number of teachers feel emotionally drained, stressed and even burnt out from their work. For the majority of teachers the main source of stress seems to be their students' lack of interest in the subject, low levels of motivation in learning English and their resultant behavioural problems in class. It seems thus that the relationship with students acts at the same time as a powerful source of satisfaction and dissatisfaction for teachers. One the one hand, Greek EFL teachers view contact with students and the potential of making an impact on student progress as the most rewarding and fascinating aspect of their work and on the other, they feel discouraged, stressed and emotionally drained seeing that they are unable to get across to students due to their negative attitudes towards the subject. Indeed, this apparent paradox has been identified by various studies (Day, 2002, Vandenberghe and Huberman, 1999) which stress the centrality of teacher student relationship in enhancing teacher satisfaction and the dire consequences for it when emotional exhaustion, a sense of futility and reduced personal accomplishment creeps into teachers working lives. In other words, the results of this study confirm that student responsiveness and 
enthusiasm is a primary and central factor in the teachers' own enthusiasm and motivation. Zembylas and Papanstasiou (2004:360) explain this connection by stating: "Because of their relative isolation from other adults, teachers have little opportunity to share their successes with colleagues and administrators... This results in greater reliance on student responsiveness for the teachers' personal satisfaction".

One might argue that students' motivation and responsiveness to the subject is in large part the responsibility of the teacher. The teachers must find ways to increase and sustain student motivation and interest. But within the Greek educational context, increasing student motivation and changing deeply ingrained attitudes is not simply a matter of methodological flexibility and expertise. The source of students' apparent lack of motivation stems from society's attitudes towards what constitutes effective language learning and from the status of the subject within the public school curriculum.

In essence the Greek public school EFL teacher is charged with an almost impossible task: he/she must struggle to find ways to motivate a student body which has been brought up to believe that language learning is effective only when it leads to the acquisition of a certificate, a certificate which requires years of preparation in the well resourced context of private language schools, a certificate for which families must pay dearly for; a certificate for which the public primary or secondary school cannot prepare them for.

Society's attitudes towards what constitutes effective language learning coupled with the deregulation of English as a secondary less important subject in the school curriculum, the near absence of substantial foreign language instruction in higher secondary school, lack of essential instructional resources in public schools, the incompatibility of curriculum principles and objectives with teaching materials can all be held accountable for students' lack of motivation.

Changing society's attitudes towards the role and purpose of foreign language education is certainly not a straightforward task and not within the realm of responsibility of the Greek EFL teacher. Changes must first occur at the language policy making level especially since the majority of Greek EFL teachers expressed dissatisfaction with aspects of their work within the realm of educational policy. Increased teacher compensation, more effective and systematic professional development opportunities, more resources for the support of teaching, better working conditions, teachers' participation in decision making and reform efforts, increased administrative support, more substantial foreign language instruction throughout compulsory education, and perhaps the introduction of a certificate of language proficiency in public education compatible with principles of the curriculum may all result in increased teacher job satisfaction and in a gradual change of student and society's perception of the quality of language teaching in public schools and their attitudes towards what constitutes effective language learning. Indeed it is for everybody's benefit - national governments', local school boards', parents' and students' - to support teacher motivation and to improve teachers' working lives in order to ultimately achieve higher quality foreign language education.

\section{REFERENCES}

Bandura, A. (1997). Self-efficacy: The Exercise of Control, New York: W.H. Freeman.

Barmby, P. (2006). "Improving teacher recruitment and retention: the importance of workload and pupil behaviour", in Educational Research, 48, 3:247-265. 
Crossman, A. and Harris, P. (2006), "Job satisfaction of secondary school teachers", in Educational Management Administration and Leadership, 34, 1: 29-46.

Bishay, A. (1996). "Teacher motivation and job satisfaction: A study employing the experience sampling method", in Journal of Undergraduate Science, 3: 147-154.

Day C. (2002). "The challenge to be best: reckless curiosity and mischievous motivation", in Teacher and Teaching: Theory and Practice 8, 3/4: 421-434.

Day, C., Stobart, G., Sammon, P. and Kington, A. (2006). "Variations in the work and lives of teachers relative and relational effectiveness", in Teachers and Teaching: Theory and Practice, 12, 2: 169-192.

Dinham, S. and Scott, C. (1998). "A three domain model of teacher and school executive career satisfaction", in Journal of Educational Administration, 36,4: 362-378.

Evans, L. (1997). "Addressing problems of conceptualization and construct validity in researching teachers' job satisfaction", in Educational Research, 39, 3: 319-331.

Evans, L. (2001). "Delving deeper into morale, job satisfaction and motivation among education professionals", in Educational Management and Administration, 29, 3: 291-306.

Farber, B. (1982). "Stress and burnout: Implications for teacher motivation" Paper presented at the Annual Meeting of the American Educational Research Association, New York, March 1982.

Hargreaves, A. (1994). Changing Teachers, Changing Times: Teachers' Work and Culture in the Postmodern Age, New York: Teachers College Press:

Hargreaves, A. (1998). "The emotional practice of teaching", in Teaching and Teacher Education, 14, 8: 835-854.

Houtte Van M. (2006). "Tracking and Teacher satisfaction: Role of study culture and trust", in The Journal of Educational Research, 99, 4: 247-254.

Huberman, M. (1993). The Lives of Teachers. London: Cassell.

Koustelios, A. (2005). "Physical education teachers in Greece: Are they satisfied?", in International Journal of Physical Education, 42, 2: 85-90.

Kyriakou, C. and Sutcliffe, J. (1979), "Teacher stress and satisfaction”, in Educational Research 21, 2: 89-96.

Neves de Jesus, S. and Lens, W. (2005). "An integrated model for the study of teacher motivation", in Applied Psychology: An International Review, 54, 1: 119-134.

Moran, A., Kilpatrick, R., Abbott, L., Dallat, J. and McClune, B. (2001). Training to teach: motivating factors and implications for recruitment, in Evaluation and Research in Education, 15: 1732.

Morgan, M. and O'Leary, M. (2004). “A study of factors associated with the job satisfaction of beginning teachers", in The Irish Journal of Education, Vol. XXXV: 73-86.

Morgan, M., Kitching, K. and O'Leary, M. (2007). "The psychic rewards of teaching: Examining global, national and local influences on teacher motivation", Paper presented at AERA annual meeting, Chicago, April 2007.

Pajares, F. (1997). "Current directions in self-efficacy research", in Maechr, M. and Pintrich, P. (eds.), Advances in Motivation and Achievement. Greenwich: JAI Press.

Papanastasiou, E.C. and Zembylas, M. (2005). "Job satisfaction variance among public and private kindergarten school teachers in Cyprus", in International Journal of Educational Research, 43: 147-167.

Scott, C. and Dinham S. (2003). "The development of scales to measure teacher and school executive occupational satisfaction", in Journal of Educational Administration, 41. 1:74-86.

Shann, M.H. (1998). "Personal commitment and satisfaction among teachers in urban middle schools", in The Journal of Educational Research, 92, 2: 67-73. 
Tschannen-Moran, M. and Woolfolk Hoy, A. and Hoy W.K.(1998), "Teacher efficacy: Its meaning and measure", in Review of Educational Research, 54: 143-178.

Vandenberghe, R. and Huberman, A.M. (1999). Understanding and Preventing Teacher Burnout. Cambridge: Cambridge University Press.

Woods, A.M. and Weasmer, J. (2004). "Maintaining job satisfaction. Engaging professional as active participants", in College Teaching, 77, 3: 118-121.

Woods, P., Jeffrey, G. and Boyle, M. (1997). Restructuring Schools, Restructuring Teachers: Responding to Change in the Primary School. Buckingham: Open University Press.

Zembylas, M. and Papanastasiou, E. (2004). "Job satisfaction among school teachers in Cyprus", in Journal of Educational Administration, 42, 3: 357-374. 
APPENDIX 1

EFL Teacher Motivation and Job Satisfaction questionnaire

\section{Background Information}

\begin{tabular}{|l|c|c|c|c|}
\hline \multirow{2}{*}{ A. Age } & $22-30$ & $31-40$ & $41-50$ & $50+$ \\
\cline { 2 - 5 } & & & & \\
\hline
\end{tabular}

\begin{tabular}{|l|l|l|}
\hline \multirow{2}{*}{ B. Gender } & Male & Female \\
\cline { 2 - 3 } & & \\
\hline
\end{tabular}

\section{Total number of years} service in teaching

\begin{tabular}{|l|l|l|}
\hline $\begin{array}{l}\text { D. Type(s) of school(s) in which you taught in } \\
\text { the past }\end{array}$ & $\begin{array}{l}\text { Please tick } \\
\text { more than once } \\
\text { if necessary. }\end{array}$ & $\begin{array}{l}\text { Number of } \\
\text { years service }\end{array}$ \\
\hline a. Public primary school & & \\
\hline b. Public secondary school & & \\
\hline c. Public Technical vocational school & & \\
\hline d. Private primary school & & \\
\hline e. Private secondary school & & \\
\hline f. Private language school (frontistirio) & & \\
\hline g. Other (please specify) & & \\
\hline
\end{tabular}

\begin{tabular}{|l|l|l|}
\hline $\begin{array}{l}\text { E. Type of school in which you currently teach (please } \\
\text { tick) }\end{array}$ & $\begin{array}{l}\text { Number of years } \\
\text { service }\end{array}$ \\
\hline a. Public Primary school & & \\
\hline b. Public secondary school & & \\
\hline c. Public Technical vocational school & & \\
\hline d. Private primary school & & \\
\hline e. Private secondary school & & \\
\hline f. Private language school (frontistirio) & & \\
\hline g. Other (please specify) & & \\
\hline
\end{tabular}

F. Geographical Area of school in which you currently teach (please state city/town/village) 


\section{G. Job satisfaction}

Please tick your degree of satisfaction with each of the statements below.

\begin{tabular}{|c|c|c|c|c|}
\hline How satisfying do you find: & $\begin{array}{l}\text { Highly } \\
\text { satisfying }\end{array}$ & Satisfying & $\begin{array}{l}\text { Neither satisfying } \\
\text { nor dissatisfying }\end{array}$ & Dissatisfyir \\
\hline \multicolumn{5}{|l|}{$\begin{array}{l}\text { 36.the amount of recognition you receive } \\
\text { for your efforts from people in your } \\
\text { school. }\end{array}$} \\
\hline \multicolumn{5}{|l|}{$\begin{array}{l}\text { 37.the amount of recognition you receive } \\
\text { for your efforts from your } \\
\text { employer/school governing body. }\end{array}$} \\
\hline \multicolumn{5}{|l|}{$\begin{array}{l}\text { 38.the amount of recognition you receive } \\
\text { for your efforts from parents and your } \\
\text { community. }\end{array}$} \\
\hline \multicolumn{5}{|l|}{$\begin{array}{l}\text { 39.the amount of recognition you receive } \\
\text { for your efforts from your students. }\end{array}$} \\
\hline \multicolumn{5}{|l|}{$\begin{array}{l}\text { 40.your status as an EFL teacher in } \\
\text { society. }\end{array}$} \\
\hline \multicolumn{5}{|l|}{$\begin{array}{l}\text { 41.your status as an EFL teacher in your } \\
\text { school. }\end{array}$} \\
\hline \multicolumn{5}{|l|}{$\begin{array}{l}\text { 42.the image of EFL teachers as } \\
\text { portrayed in the media. }\end{array}$} \\
\hline \multicolumn{5}{|l|}{$\begin{array}{l}\text { 43.the way that educational professional } \\
\text { associations work for the betterment } \\
\text { of your profession. }\end{array}$} \\
\hline \multicolumn{5}{|l|}{$\begin{array}{l}\text { 44.the way that governments work for the } \\
\text { betterment of your status. }\end{array}$} \\
\hline \multicolumn{5}{|l|}{$\begin{array}{l}\text { 45.the range of professional in-services } \\
\text { courses/programmes/support offered } \\
\text { to EFL teachers }\end{array}$} \\
\hline \multicolumn{5}{|l|}{ 46.your salary. } \\
\hline \multicolumn{5}{|l|}{$\begin{array}{l}\text { 47.your opportunities for promotion or } \\
\text { advancement }\end{array}$} \\
\hline \multicolumn{5}{|l|}{$\begin{array}{l}\text { 48.the physical working environment of } \\
\text { your school (infrastructure, resources } \\
\text { etc.). }\end{array}$} \\
\hline \multicolumn{5}{|l|}{$\begin{array}{l}\text { 49.your benefits (holidays, educational } \\
\text { leaves etc.). }\end{array}$} \\
\hline $\begin{array}{l}\text { 50.your "official" working hours (in } \\
\text { terms of quantity). }\end{array}$ & & & & \\
\hline
\end{tabular}




\section{H. Teacher Motivation}

Below is a series of statements relating to factors which have been found to affect teacher motivation. Please read each statement and tick your degree of agreement or disagreement with each one.

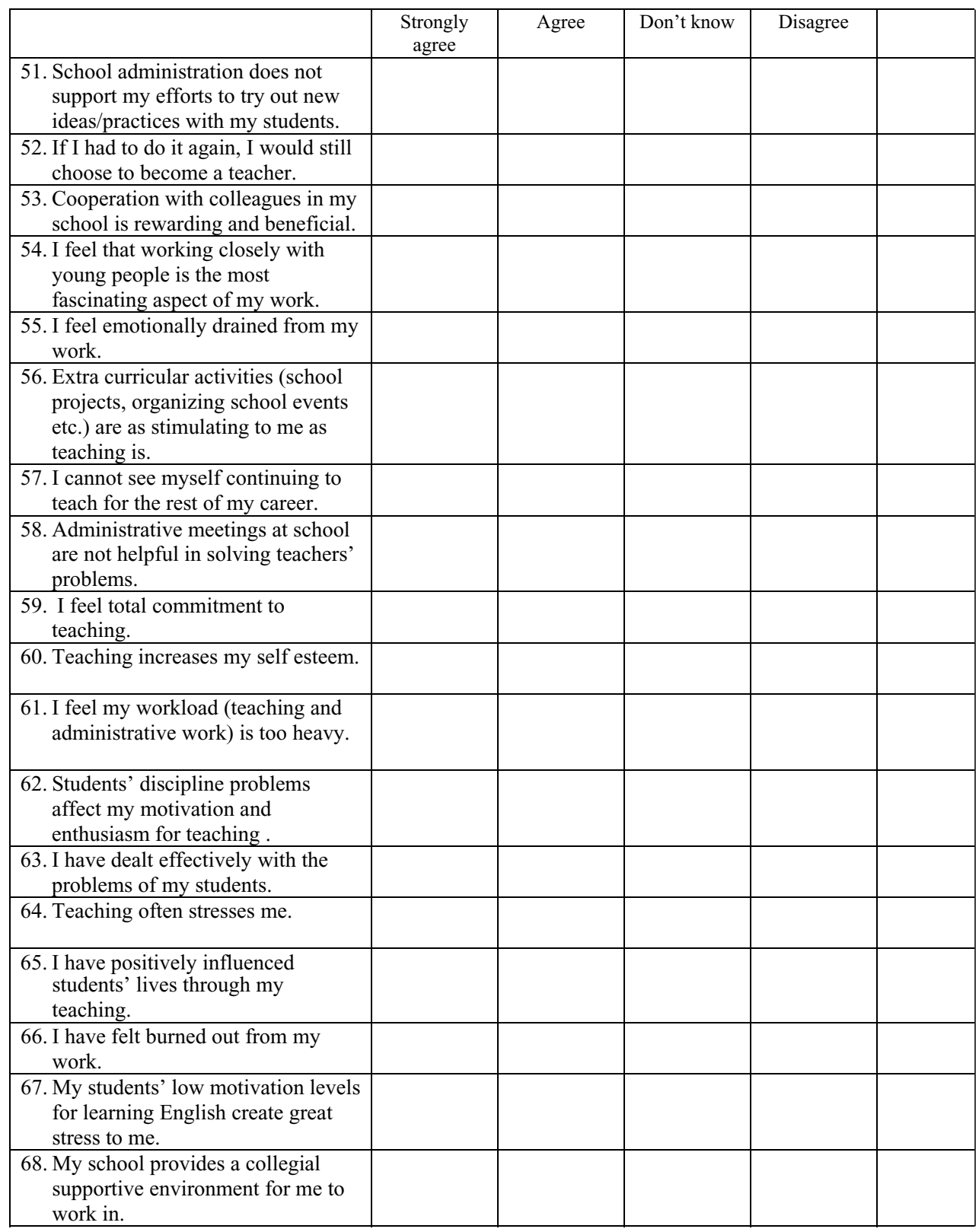




\begin{tabular}{|l|l|l|l|l|l|}
\hline $\begin{array}{l}\text { 69. I find my work mentally } \\
\text { stimulating. }\end{array}$ & & & & \\
\hline $\begin{array}{l}\text { 70. Students' attitude problems } \\
\text { (misbehaviour in class, lack of } \\
\text { interest in the subject etc.) have an } \\
\text { effect on the quality of my }\end{array}$ & & & & & \\
teaching. & & & & & \\
\hline
\end{tabular}

\section{What were your main reasons for entering the teaching} profession (tick more than one if necessary)

\begin{tabular}{|l|l|}
\hline 14. Working with young people & \\
\hline 15. Salary and benefits & \\
\hline 16. Job security & \\
\hline 17. Teaching fitted in with my lifestyle/family situation & \\
\hline 18. Variety in teaching & \\
\hline 19. Mentally stimulating work & \\
\hline 20. Love of the subject & \\
\hline 21. Promotion prospects & \\
\hline 22. Contributing to society & \\
\hline 23. Status of the profession & \\
\hline 24. Potential of changing students' lives/attitudes & \\
\hline 25. Family approval & \\
\hline 26. Other (please state) &
\end{tabular}

